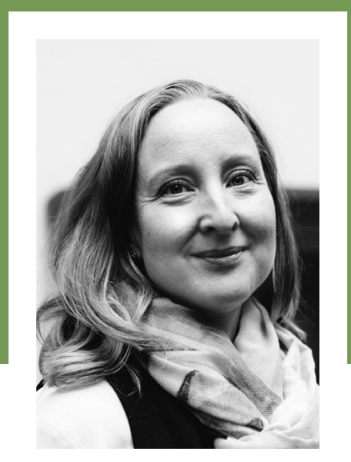

\title{
P̈̈̈̈KIRJOITUS
}

\section{AikUiskoUlUTUKSEEN KOHDISTUVAT ODOTUKSET EIVÄT SYNNY TYHJÄSTÄ}

$\mathrm{P}$ AREMMAN ELÄMÄN TAITO -kirjassaan sveitsiläinen filosofi ja kirjailija Rolf Dobelli kehottaa meitä olemaan tarkkana odotustemme suhteen. Hän suosittelee erittelemään tarpeet, toiveet ja odotukset toisistaan. On asioita, joiden toteutumista pidämme täysin välttämättöminä ja sitten niitä, joista unelmoimme ja joita mielellään haluaisimme saavuttaa elämässämme. Lisäksi meillä on tulevaisuutta ja muita ihmisiä koskevia odotuksia, jotka huomaamatta ohjaavat tekojamme. Odotuksia kannattaa rakentaa tietoisesti ja välttää turhien pakkojen ja toiveiden kasvattamista suhteettoman suuriksi.

MINKÄLAISET ODOTUKSET OHJAAVAT aikuiskoulutukseen osallistumista? Pidetäänkö koulutusta välttämättömänä suorituksena, jota ilman ei voi tavoitella hyvää elämää? Ohjaako kouluttautumista toive, että opinnot avaavat ovia muidenkin unelmien saavuttamiseen? Vai onko aikuisopiskelusta tullut niin itsestään selvää, että osallistumisen syitä ja seurauksia ei tule sen kummemmin pohdittua? Kouluttaudumme, koska niin kuuluu tehdä ja niinhän kaikki muutkin tekevät.

Koulutustoiveisiimme ja -odotuksiimme vaikuttavat opiskelun yleisyys ja väestön yleinen koulutustaso. Korkeakoulutuksen laajenemista tutkinut professori
Martin Trow esitti 1970-luvulla klassikoksi muodostuneen jaottelun eliitti-, massa- ja universaaliin korkeakoulutukseen. Kun väestöstä yli 15 prosenttia osallistuu korkeakoulutukseen, siirrytään pienen eliitin koulutuksesta massakorkeakoulutukseen. Korkeakouluopintojen yleistyessä opiskelijat eivät enää pidä opiskelumahdollisuuksiaan etuoikeutena vaan jokaiselle kansalaiselle kuuluvana oikeutena. Universaalissa vaiheessa yli puolet ikäluokasta osallistuu korkeakoulutukseen, jolloin kouluttautumisesta tulee kansalaisoikeuden sijaan velvollisuus. (Trow 1974.)

Aikuiskoulutuksessa ei ole käytetty vastaavaa luokittelua. Koska Suomessa noin puolet aikuisväestöstä osallistuu vuosittain erilaisiin koulutuksiin, voimme ajatella elävämme massa-aikuiskoulutuksen aikaa.

TILASTOKESKUKSEN TUOREIMMASSA aikuiskoulutustutkimuksessa universaalin kouluttautumisen raja ylittyi nuorilla aikuisilla, pitkän pohjakoulutuksen hankkineilla, toimihenkilöillä, työssä käyvillä ja kaupunkilaisilla. He pitävät jatkuvaa opiskelua miltei pakottavana: ilman sitä ei pärjää eikä menesty elämässä. Kolme yleisintä, keskenään tasaveroista syytä tutkintoon johtavaan aikuiskoulutukseen osallistumiseen olivat 1) tietojen ja taitojen kehittäminen 


\title{
KOULUTUS MAHDOLLISTI PÄÄSYN
}

\section{TYÖTEHTÄVIIN, JOISSA OLI ENEMMÄN}

\author{
VAIKUTUSMAHDOLLISUUKSIA.
}

itselle mielenkiintoisista aiheista, 2) uranäkymien kehittämien ja 3) paremmat mahdollisuudet työpaikan saamiseen tai ammatin vaihto. Erityisesti miehet pitivät myös muodollista tutkintoa tärkeänä. (Tilastokeskus 2018.)

Entä miksi uuden oppiminen ilman muodollisia pätevyyksiä ei riitä? Isossa-Britanniassa tutkittiin hiljattain polkuja aikuiskoulutuksesta laaja-alaiseen hyvinvointiin kansallisen pitkittäisaineiston avulla (Jenkins \& Wiggins 2017). Tutkintotavoitteinen aikuiskoulutus lisäsi keski-ikäisten tyytyväisyyttä elämään.

Tutkinnon päivittäminen tai erityispätevyyden hankkiminen ei kuitenkaan ollut automaattisesti ja suoraan yhteydessä kokonaishyvinvointiin, koettuun työstressiin tai työtyytyväisyyteen. Sen sijaan hyvinvointi lisääntyi pitkällä tähtäimellä siksi, että koulutus mahdollisti pääsyn laadullisesti aiempaa parempiin työtehtäviin, joissa oli enemmän vaikutusmahdollisuuksia. Vahvin yhteys koettuun hyvinvointiin oli korkeakoulututkinnon suorittamisella, sillä se mahdollisti siirtymisen sosiaalisesti arvostettuihin asiantuntija-, esimies- ja johtotehtäviin.

AIKUISTEN KOKEMAN KOULUTUSPAKON yksi keskeinen syy on koulutuksen inflaatio. Korkeakoulutuksen laajentumisen myötä yhä useampi suorittaa ylemmän korkeakoulututkinnon, johon suhteutettuna alempien tutkintojen ja muiden pätevyyksien arvo laskee. Samaa yhteiskunnallista ja ammatillista asemaa tavoitellakseen on siten opiskeltava yhä enemmän ja enemmän.
Koulutusinflaatio kolahtaa erityisesti ikääntyviin työikäisiin. He kilpailevat työmarkkinoilla nuorempien työnhakijoiden kanssa, joille mittavammat koulutukselliset ansiot tarjoavat etulyöntiaseman. Kilpailua käydään myös koulutukseen pääsystä.

Aikuiskoulutukseen osallistumiseen kohdistuvat paineet eivät synny tyhästä. Onko brittitutkimuksen mukaisesti pääteltävissä, että ne, jotka sisäistävät odotuksen aikuisopiskelun välttämättömyydestä, lisäävät samalla hyvinvointinsa todennäköisyyttä pitkällä tähtäimellä? Yhteys on olemassa. Siitä huolimatta, Dobellin kirjan ajatuksia soveltaen, harvat koulutusta ja työelämää koskevat toiveet ovat elämällemme elintärkeitä ja ensisijaisia. Ja myös muodollisessa koulutuksessa hyvinvointia vahvistaa välineellisten odotusten rinnalla oppimisesta itsestään saatu ilo.

Ulpukka Isopahkala-Bouret

\section{Kirjallisuus:}

Dobelli, R. (2018). Paremman elämän taito. 52 reittiä onnellisuuteen. Jyväskylä: Atena.

Jenkins, A. \& Wiggins, R. (2017). Pathways from adult education to well-being: The Tuijnman model revisited. International Review of Education 61, 79-97.

Trow, M. (1974). Problems in the Transition from Elite to Mass Higher Education. Policies for Higher Education, Paris: OECD, 51-104.

Tilastokeskus (2018). Osallistuminen aikuiskoulutukseen vuonna 2017. http://www.stat.fi/tup/julkaisut/tiedostot/ julkaisuluettelo/ykou_aku_201700_2018_19724_net.pdf. 